\title{
Introduction of TPACK in Mathematics Education Realm
}

\author{
Yenny Anggreini Sarumaha \\ Cokroaminoto University of Yogyakarta, Jl. Perintis Kemerdekaan, Gambiran, Yogyakarta, Indonesia \\ Email: yanggreini@gmail.com
}

\begin{abstract}
Mathematics education is one of the fields that agrees about the importance of integrating technologies into instructional activities in the classroom. However, only understanding technologies does not full fill the criteria of effective teachers, they have to be prepared and grasp the ideas of combining technologies, pedagogical, and content knowledge. This present study is a literature review which aimed at answering two mains questions namely, what is the TPACK framework and how does it influence our education system. Data were collected from articles related to technologies, ICT, and TPACK from thematic journals. The results found that TPACK is a well-known theoretical approach studying the pre-service teachers' use of ICT. TPACK is accepted as an important framework for defining how well teachers integrate technologies in their classroom. TPACK model shows an effective way of thinking about integrating technologies along with pedagogies, and content knowledge. It has been developed for twenty-first century skills and used as a framework for developing teachers' readiness toward the twenty-first century skills.
\end{abstract}

Keywords: TPACK framework, ICT in education, technological knowledge, pedagogical knowledge, content knowledge.

\begin{abstract}
Abstrak
Pendidikan Matematika adalah salah satu cabang ilmu yang setuju tentang pentingnya pengintegrasiaon teknologi dalam pembelajaran di kelas. Namun, hanya memahami teknologi tidaklah cukup untuk memenuhi kriteria guru efektif, guru harus dipersiapkan dan menangkap ide untuk mengkombinasikan pengetahuan terkait teknologi, pedagodi, dan konten. Studi ini merupakan studi literatur yang bertujuan untuk menjawab dua pertanyaan utama yaitu, apa yang dimaksud dengan model TPACK dan bagaimana model ini mempengaruhi sistem pendidikan kita. Data dikumpulkan dari berbagai artikel yang berhubungan dengan teknologi, ICT dan TPACK dari berbagai jurnal yang berhubungan. Hasil yang diperoleh menunjukkan bahwa TPACK adalah pendekatan teoritis yang telah dikenal dalam mempelajari kemampuan calon guru menggunakan ICT. TPACK telah diterima sebagai model yang penting untuk mendefinisikan seberapa baiknya guru mengintegrasikan teknologi sejalan dengan pedagogi dan pengetahuan tentang konten. TPACK telah dikembangkan sejalan dengan kemampuan abad 21 and digunakan sebagai model untuk mengembangkan kesiapan guru menghadapi kemampuan abad 21.
\end{abstract}

Kata kunci: model TPACK, ICT dalam pendidikan, pengetahuan teknologi, pengetahuan pedagogis, pengetahuan konten

How to Cite: Sarumaha, Y. A. (2019). Introduction of TPACK in mathematics education realm. Jurnal Pendidikan Matematika, $x(\mathrm{x}), \mathrm{xx}-\mathrm{xx}$.

\section{INTRODUCTION}

The development of ICT undeniably plays an important role in today's lives. Saljo (2010) stated that digital technology has in recent decades seen enormous development. It has induced major changes in any aspects of our daily activities. The changes which are happening on the digital side also give a great impact in the field of education and they are creating new expectations for today's schools and teachers. In 2011, The Horizon Report showed the trends in education immensely used internet in any aspects, for instance, through smart phones which was increasingly demanded. 
The development in technological and pedagogical areas provides several new opportunities for supporting teaching and learning process. Teachers are facing all kinds of digital tools related to their work. Students in the other hand engaged with a variety of information and knowledge channels. However, there are also some parts which have to be considered while integrating technology in education. Petko et al. (2018) mentioned schools' readiness such as support, resources, perceived importance of ICT integration and the sharing ideas between teachers, as a vital part for ICT integration. It is not far from what Brinkerhoff (2006) suggested about facilitating conditions, support and administration as important factors for integrating ICT in school practices.

Jurnal Intersections provides a forum for publishing the original research articles, review articles from contributors, and the novel technology news related to mathematics educatio In order to achieve the effectiveness of using ICT in teaching and learning, teachers have to understand how ICT connects with pedagogy and content. It becomes one of most countries' challenging issues where the teachers' quality in the $21^{\text {st }}$ century is questioned. The quality of teachers is the key to quality of education since the effectiveness of the teachers is related to the quality of the graduated students. A lot of school nowadays are increasingly provided with ICT. Government invests in ICT resources for schools and formulate regulation for teacher's education institute with expectations that the preservice teachers become teachers who prepare for current modern learning environment. Since the increasing of ICT availability, preparing future teachers to effectively integrate ICT into classroom instruction becoming a continuing issue which requires resources, expertise and planning (UNESCO, 2002) to assist and guide pre-service teachers to accommodate themselves at schools.

NCTM (2008) also recognized ICT as a part of education by stating technology is an essential tool for learning mathematics in the $21^{\text {st }}$ century, and all schools must ensure that all their students have access to technology. It happens to be one of the challenging issues for mathematics teachers in order to effectively use ICT in teaching. The immense of the changes in technology also pose challenges for pre-service teachers, demanding new skills and knowledge to take advantage of the new technologies in pedagogically meaningful ways. As Dewey (1916) says, "If we teach today as we taught yesterday, then we rob our children of tomorrow." By changing teacher training and providing appropriate technical experience can we improve mathematics education (Landry, 2010).

Facts from interviews gathered from some teachers and classroom observations give impression that teachers face difficulties adapting and implementing ICT in the lessons. They tend to deliver the materials by explaining whole subjects, giving examples, and exercises without a hint in using technology. This becomes a major problem in encouraging students to love learning mathematics since they have already had experiences in various visuals views, sounds, and buttons. Learning at school is more likely tedious activities compare with activities in their phones using internet access. Kay (2006) and Yildirim (2000) in their studies showed that pre-service teachers are not ready to use ICT in education and to effectively integrate ICT into classroom instructions.

In 2006, Mishra and Koehler proposed a framework of Technological pedagogical Content 
Knowledge (TPACK) that clarifies the need to develop the ICT, pedagogy, and content knowledge separately and together to effectively integrate ICT in teaching. It implies that effective use of ICT in teaching and learning requires teacher to understand how ICT connect with pedagogy and content. Then some questions raise from this background. This literature study attempts to unravel some common questions around TPACK and its influence in education especially mathematics education. The questions that need to address in this literature study are (1) what is the TPACK framework? and (2) how does it influence our education system?

\section{METHODS}

This present study is a literature review. A literature review can broadly be described as a nore or less systematic way of collecting and synthesizing previous research (Tranfield, Denyer, \& Smart, 2003). This method was chosen since an effective and well conducted review as a research method creates a firm foundation for advancing knowledge and facilitating theory development (Webster \& Watson, 2002). By integrating findings and perspectives from many empirical findings, a literature review can address research questions with a power that no single study has.

Data were collected from sorting out articles related to TPACK and ICT in education. Articles are gathered from a collective of credible journals and listed which were address the main questions propose in this literature review. Researcher searched the answers of the questions through the articles and started make notes to elaborate the answers.

\section{RESULTS AND DISCUSSION}

\section{ICT in Mathematics Education}

ICT can be defined as the diverse set of technological tools known as hardware and resources from application and software which are used to communicate, to create, to disseminate, to store, and to manage information. The now ICT are the combination amongst all, hardware, software, media, and delivery system for instance desktop, laptop, notebook, handphones, digital cameras, CD-ROMs, DVDs, and other virtual or electronic devices. According to Davis (2010) there are five major strategies that have been commonly implemented in order to integrate ICT in teaching and learning process during Initial Teacher Education (ITE) program, namely: (1) stand-alone technology course; (2) workshops; (3) integrating ICT in method and foundation course; (4) modeling how to use ICT; (5) early field experience and a later practicum in schools that include ICT.

NCTM (2014) stated that one of the guiding principles is principle to actions to ensure mathematics success for all where teachers are asked to use tools and technology and make sense of mathematics, reason mathematically, and communicate mathematical thinking. NCTM suggests when tools and technology are used appropriately, they support effective teaching and promote meaningful 
learning. However, how the technology is used is dependent on the teachers and their knowledge. As pointed out by Drijvers (2012) that the teacher has to orchestrate learning, for example by synthesizing the results of technology-rich activities, highlighting fruitful tool techniques, and relating the experiences within technological environment to paper-and-pen skills or to other mathematical activities. In other words, teachers should integrate knowledge of students thinking and learning strategies along with knowledge of the subject with the use of digital tools in their teaching.

When talking about teachers' integration of technology, there are two types barriers. The first barrier related to resources such as access to digital tools, software, internet, and time to plan and teach technology-based lessons. It also includes technology training and support, which contribute to teachers' knowledge of technology and how to integrate it into their practice. The second one is typically rooted in teachers' underlaying beliefs about teaching and learning and not directly apparent to others or even to the teachers themselves. The first barrier clearly can be eliminated if money is allocated while the latter is less tangible, more personal, and more deeply ingrained that the other (Ertmer, 1999).

\section{Improving Pre-Service Teachers' Skills}

One of many famous adages mentioned by Albert Einstein that the only source of knowledge is experience. Related to teaching and learning in the classroom, Doering, Hughes, and Huffman (2003) stated that field experience is one way to increase knowledge and skills of pre-service teachers. Field experience is attained through real-life activities in teaching a large group of students in the classroom. Some benefits gained from field experience include:

- exposing pre-service teachers to participation in cooperative learning

- opening new opportunities for pre-service teachers to learn from other professional teachers who are experts in the use of technology in teaching

- increasing pre-service teachers' exposure to opportunities to make important teaching and learning decisions

- allowing pre-service teachers to gain more access to technological tools which can be used in teaching

The field experience program in pre-service teachers' education curriculum gives opportunity to enhance their skills in conducting teaching in the classroom. Another aspect that should be considered during field experience is a good support from associate teacher who is sufficient in teaching experience and successful supervisions from prior pre-service teachers. In other words, to attained the good result, pre-service teachers need to receive adequate support and knowledge from their associate teachers, advisors, and cooperating teachers. 


\section{The Theory Behind the TPACK Framework}

According to Alayyar, Fisser, and Voogt (2012), pre-service teachers are being prepared to continue throughout their career to improve the effectiveness of their teaching methods, to learn more about the use of ICT, to increase their knowledge of certain subject matter, and to know how the students think and learn. In other words, it is a way to gather knowledge about how to teach, what to teach, and how to do so with the use of ICT. In technology with enhanced learning environment, preservice teachers are expected to become creative. For example, they can combine the use of online lectures and classroom discussions to ask students to create their own learning videos. Mishra and Koehler (2006) stated that before they can become creative in the use of ICT in schools, pre-service teachers should first be able to understand the linkages between technological knowledge, pedagogical knowledge, and content knowledge.

Technology, Pedagogy, and Content Knowledge Framework known as TPACK by Mishra and Koehler (2006) provides a mean to examine both the specialized and intertwined knowledge teachers need to effectively integrate technology into the classroom. They define TPACK as the basis of good teaching with technology and requires an understanding of the representation of concepts using technologies; pedagogical techniques that use technologies in constructive ways to teach content; knowledge of what makes concepts difficult or easy to learn and how technology can help redress some of the problems that students face; knowledge of students' prior knowledge and theories of epistemology; and knowledge of how technologies can be used to build on existing knowledge and to develop new epistemology or strengthen old ones. This knowledge is important in helping teachers develop powerful ways of teaching with technology in the classroom and for helping students to construct knowledge using technology.

Polly and Brantley-Dias (2009) stated that the TPACK model presents an effective way of thinking about integrating technology through the provision of specific knowledge associated with technology integration into learning environments. The TPACK frameworks presented by Mishra and Koehler (2006) was derived from Shulman's Pedagogical Content Knowledge (PCK) model. Shulman (1986) stated that pedagogical content knowledge (PCK) is a specific category of knowledge which goes beyond knowledge of subject matter per se to the dimension of subject matter knowledge for teaching.

TPACK has three basic types of knowledge: that is Technological Knowledge (TK), Content Knowledge (CK), and Pedagogical Knowledge (PK). Figure 1 shows the connection of the three types for teaching and learning which related to each other. 


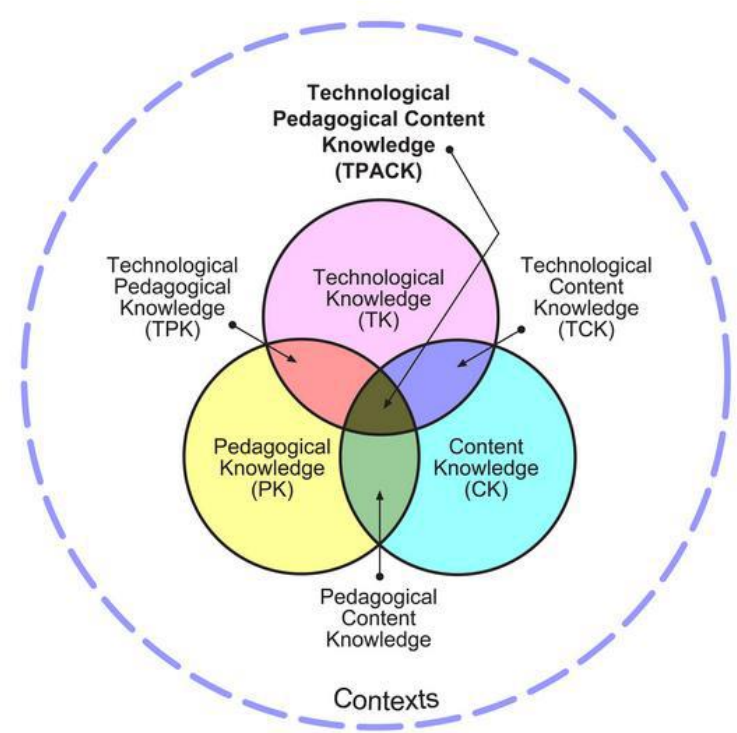

Figure 1. Technological Pedagogical Content Knowledge (retrieved from www.tpack.org)

The TPACK framework is more complex since the model is composed of seven constructs known as,

\section{Technological Knowledge (TK)}

TK refers to knowledge needed to adapt the fast development of technology without focusing on teaching and learning. As stated by Baran, Chuang, \& Thompson (2011), TK is all about effectively managing and maintaining the condition of high- and low- technologies including ICT such as wireless broadband, dial-up internet connection, creating digital photos and videos, hardware and software programs, and the management of interactive whiteboards, blackboards, etc. TK can also refer to the best way of optimizing students' learning by being able to accurately identify useful technologies that can be used in teaching (Mishra \& Koehler, 2006).

\section{Content Knowledge (CK)}

Schulman (1986) defined CK as the amount and organization of knowledge per se in the mind of teacher. It is knowledge about the taught subject matter containing knowledge of theories, concepts and practices in the field. CK contain deep knowledge fundamentals of the disciplines without consideration about teaching the topic. It is very important to ensure that all teachers strengthen their knowledge of content so that they are all capable in helping students construct their understandings.

3. Pedagogical Knowledge (PK)

PK refers to knowledge that has been gained through collected practices, processes, strategies, procedure, and methods of teaching and learning (Koehler \& Mishra, 2005). In other words, it is knowledge of teaching and learning practices, knowledge of classroom management and assessment, knowledge of how students construct knowledge. Furthermore, PK focuses on 
learning theories in general without focusing on teaching certain contents which will enable teachers to use several approaches in delivering the content to students.

\section{Pedagogical Content Knowledge (PCK)}

As it named, PCK means the knowledge of pedagogy that is applicable to a specific content area. Schulman (1986) stated that PCK pertains to the manner in which the content can be represented and formulated to make it comprehensible to others. It is commonly used to improve the outcome of the teaching process. PCK is knowledge of transforming the subject matter knowledge for teaching, organize conditions for making the learning of certain content easy. PCK also contain knowledge of typical misconceptions related to a specific content area.

\section{Technological Content Knowledge (TCK)}

Koehler and Mishra (2009) stated TCK is basically an understanding of the manner in which technology and content influence and constrain one another. TCK is considered as knowledge of how technology and content influence one another, knowing the technologies used within different subject matter areas. TCK consists of knowledge how subject matter develop with technology, without considering teaching the content area.

6. Technological Pedagogical Knowledge (TPK)

It is known as knowledge of how to support certain pedagogical approaches with appropriate technology, to know pedagogical benefits and constraints of different technologies. TPK is about having the knowledge of how to improve teaching and learning process when technologies are being fully utilized (Harris, Mishra, \& Koehler, 2009). Align with TK, TPK refers to forward-looking technology use in order to find best ways to support learning without focusing certain content areas. In other words, TPK is about how pedagogies change while using ICT.

\section{Technological Pedagogical Content Knowledge (TPACK)}

TPACK is knowledge of using various technologies and pedagogical approaches while teaching different contents. It arises out of the intersection between the knowledge of content, technology, and pedagogy which can be defined as knowing how to represent subject matter with technology in pedagogically sound ways. Understanding that emerges when combining CK, TK, and PK, knowledge underlaying skilled teaching with technology. This framework is applicable to all pre-service teachers in which the process of developing knowledge of technology, pedagogy, and content is important to prepare them to face the challenges when integrating ICT into classroom instruction.

The pre-service teachers are expected to comply the content, technology, and pedagogy in order to improve their teaching and learning with technology. As stated by Koehler and Mishra (2008), TPCK is different from knowledge of all three concepts individually, the basis of effective teaching with 
technology requires an understanding of the representation of concepts using technologies; pedagogical techniques that use technologies in constructive ways to teach content; knowledge of what makes concepts difficult or easy to learn and how technology can help redress some of the problems that students face; knowledge of students' prior knowledge and theories of epistemology; and knowledge of how technologies can be used to build on existing knowledge and to develop new epistemologies or strengthen old ones.

\section{Teachers' pedagogical beliefs and technology integration}

Ertmer (2005) stated that the nature of teachers' pedagogical beliefs is an important part for successful technology integration. According to Swars et al. (2009) teachers' beliefs influence their thinking and behaviours, including instructional decision-making and use of curriculum materials, which may include the use of technology. Thus, their beliefs may profoundly shape the way that they teach. Teo and Milutionovic (2015) in their study have shown that attitudes towards the use of ICT in education play a crucial role in the intention to use ICT. Kim et al. (2013) affirmed that there is a strong relationship between teachers' beliefs and their TPACK or technology integration. Teachers' beliefs about the nature of content knowledge and learning and about effective ways of teaching were related to their technology integration practices.

Dwyer et al. (1990) found that teachers struggled implementing technology due to their traditional beliefs about teaching and learning. However, as the teachers developed their own knowledge of how to use technology and observed their students use of technology to learn, their beliefs became more student-centered and technology-friendly and they used technology more frequently and with greater fidelity in their classrooms. Beside their beliefs, teachers' knowledge influences their use of technology in the classroom (Hew \& Brush, 2007). Teachers need to have specialized and intertwined knowledge for teaching with technology. As Hughes (2005) mentioned that it is important for teachers to have technology-supported-pedagogy knowledge and skills' in order to plan to integrate technology into their teaching. Hughes added that these knowledge and skills consists of knowing what technology can do and how to use it appropriately in the classroom.

The research by Smith et al. (2016) examined relationship between prospective middle grades teachers' knowledge of how to use technology in the teaching and learning geometry and their beliefs about nature of mathematics, teaching, learning, and the use of technology. They found that there were possible relationships between their beliefs about nature if mathematics, learning and teaching mathematics, and the use of technology and their content knowledge, pedagogical content knowledge, and technological pedagogical content knowledge respectively. 


\section{CONCLUSION}

The TPACK framework shown by Mishra and Koehler in 2006 was derived from Schulman's Pedagogical Content Knowledge (PCK) model. The TPACK framework is more complete because the model is composed of seven constructs namely, Technological Knowledge (TK), Content Knowledge

(CK), Pedagogical Knowledge (PK), Pedagogical Content Knowledge (PCK), Technological Content Knowledge (TCK), Technological Pedagogical Content Knowledge (TPK), and Technological Pedagogical Content Knowledge (TPACK).

TPACK is accepted as an important framework for defining how well teachers integrate technologies into their classrooms. Before they can be creative in the use of ICT, pre-service mathematics teacher should first be able to understand the linkages among technological knowledge, pedagogical knowledge, and content knowledge. TPACK model can prepare pre-service mathematics teachers with sufficient knowledge and skills needed to enable them to fully utilize the available ICT tools in teaching.

\section{REFERENCES}

Alayyar, G. M., Fisser, P., \& Voogt, J. (2012). Developing technological pedagogical content knowledge in pre-service science teachers: Support from blended learning. Australasian Journal of Educational Technology, 28(8), 1298-1316. Retrieved from https://doi.org/10.14742/ajet.773

Baran, E., Chuang, H.-H., \& Thompson, A. (2011). TPACK: An emerging research and development tool for teacher educators. TOJET: The Turkish Online Journal of Educational Technology, 10(4), 370-377.

Davis, N. E. (2010). Technology in Preservice Teacher Education. In P. Peterson, E. Baker \& B. McGaw, (Editors). International Encyclopedia of Education, volume 8, pp. 217-221. Oxford: Elsevier.

Dewey, J. (1916). Democracy and education. New York: Free Press.

Drijvers, P. (2012). Digital technology in mathematical education: Why it works (or doesn't). Proceedings of the 12th International Congress on Mathematical Education. Seoul, Korea.

Doering, A., Hughes, J., \& Huffman, D. (2003). Preservice teachers: Are we thinking with technology? Journal of Research on Technology in Education, 35(3), 342-361

Dwyer, D. C., Ringstaff, C., \& Sandholtz, J. (1990). The evolution of teachers' instructional beliefs and practices in high access-to technology classrooms. Paper presented at the Annual Meeting of Educational Research Association, Boston.

Ertmer, P. A. (1999). Addressing first-and-second -order barriers to change: Strategies for technology integration. Educational Technology Research and Development, 47(4), 47-61. 
Ertmer, P. A. (2005). Teacher pedagogical beliefs: The final frontier in our quest for technology integration. Educational Technology Research and Development, 53(4), 25-39.

Harris, J., Mishra, P., \& Koehler, M. (2009). Teachers' technological pedagogical content knowledge and learning activity types: Curriculum-based technology integration reframed. Journal of Research on Technology in Education, 41(4), 393-416.

Hew, K. F., \& Brush, T. (2007). Integrating technology into K-12 teaching and learning: Current knowledge gaps and recommendations for future research. Educational Technology Research and Development, 55(3), 223-252

Hughes, J. (2005). The role of teacher knowledge and learning experiences in forming technologyintegrated pedagogy. Journal of Technology and Teacher Education, 13(2), 277-302.

Kay, R. H. (2006). Evaluating strategies used to incorporate technology into pre-service education: a review of the literature. Journal of Research on Technology in Education, 38(4), 383-408.

Kim, C., Kim, M. K., Lee, C., Spector, J. M., \& DeMeester, K. (2013). Teacher beliefs and technology integration. Teaching and Teacher Education, 29, 76-85.

Koehler, M. J., \& Mishra, P. (2009). What is technological pedagogical content knowledge? Contemporary Issues in Technology and Teacher Education, 9(1), 60-70.

Koehler, M., \& Mishra, P. (2008). Introducing TPCK. AACTE Committee on Innovation and Technology (Ed.), The handbook of technological pedagogical content knowledge (TPCK) for educators (pp. 3-29). Mahwah, NJ: Lawrence Erlbaum Associates.

Koehler, M. J., \& Mishra, P. (2005). What happens when teachers design educational technology? The development of Technological Pedagogical Content Knowledge. Journal of Educational Computing Research, 32(2), 131-152.

Koehler, M. J., Mishra, P., Kereluik, K., Shin, T. S., \& Graham, C. R. (2014). The technological pedagogical content knowledge framework, In Handbook of research on educational communications and technology (pp. 101-111). New York, NY: Springer. https://doi.org/10.1007/978-1-4614-3185-5_9.

Landry, G. A. (2010). Creating and Validating an Instrument to Measure Middle School Mathematics Teathers' Technological Pedagogical Content Knowledge (TPACK). Tennessee: University of Tennessee.

Mishra, P., \& Koehler, M. J. (2006). Technological pedagogical content knowledge: A framework for teacher knowledge. The Teachers College Records, 108(6), 1017-1054.

National Council of Teachers of Mathematics. (2008). The role of technology in the teaching and learning of mathematics. Retrieved from http://www.nctm.org/ uploadedFiles/About_NCTM/Position_Statements/Technology\%20final.pdf at 2013 22/4

National Council of Teachers of Mathematics (2014). Principle to actions: Ensuring mathematical success for all. Reston, VA: National Council of Teachers of Mathematics. 
Petko, D., Prasse, D., \& Cantieni, A. (2018). The interplay of school readiness and teacher readiness for educational technology integration: A structural equation model. Computers in the Schools, 35(1), 1-18. https://doi.org/10.1080/07380569.2018.1428007

Polly, D., \& Brantley-Dias, L. (2009). TPACK: Where do we go now? TechTrends, 53(5), 46-47. doi: 10.1007/s11528-009-0324-4

Säljö, R. (2010). Digital tools and challenges to institutional traditions of learning: technologies, social memory and the performative nature of learning. Journal of computer assisted learning.

Shulman, L. (1986). Those who understand: Knowledge growth in teaching. Educational Researcher, 15(2), 4-14. https://doi.org/10.3102/0013189X015002004

Smith, R. C., Kim, S., \& McIntyre, L. (2016). Relationship between prospective middle grades mathematics teachers' beliefs and TPACK. Canadian Journal of Science, Mathematics and Technology Education, DOI: 10.1080/14926156.2016.1189624.

Swars, S. L., Smith, S. Z., Smith, M. E., \& Hart, L. C. (2009). A longitudinal study of effects of a developmental teacher preparation program on elementary prospective teachers' mathematical beliefs. Journal of Mathematics Teacher Education. 12(1), 47-66.

The Horizon report. (2011). Retrieved from http://wp.nmc.org/horizon2010/ at 2011

Tranfield, D., Denyer, D., \& Smart, P. (2003). Towards a methodology for developing evidenceinformed management knowledge by means of systematic review. British Journal of Management, 14, 207-222. http://doi.org/10.1111/1467-8551.00375.

Webster, J., \& Watson, R. T. (2002). Analyzing the past to prepare for the future: Writing a literature review. Management Information Systems Quarterly, 26, 3.

Willermark, S. (2018). Technological pedagogical and content knowledge: A review of empirical studies published from 2011 to 2016. Journal of Educational Computing Research, 56(3), 315343. https://doi.org/10.1177/0735633117713114.

Yildrim, S. (2000). Effects of an Educational Computing Course on Pre-Service and In-Service Teachers: A Discussion and Analysis of Attitudes and Use. Journal of Research on Computing in Education, 32(4), 479-495 